\title{
DINAMIKA PENGEMBANGAN SISTEM PENDIDIKAN \\ (Kerangka Dasar Potensi Anak Usia Dini)
}

Amin Nasir

Dosen Jurusan Tarbiyah STAIN Kudus

\begin{abstract}
The pattern of learning in early childhood should be built based on the growth and development of children whose implementation is packed appropriately in accordance with the child's world, that is playing, drawing, singing and watching cartoons. All of them are a routine activity that is great fun for children, as well as through playing, drawing, singing children will learn Growth of children is different with their development. The growth is more quantitative, whereas the development refers to the qualitative parameters. Thus, the meaning of early childhood development is the advancement of the quality of physical function, psychological and synergy of both. Early childhood development that need to be considered further attention include areas: motor skills, physical function, cognitive ability, language skills, and the ability of religion.
\end{abstract}

Keywords: Development, systems, Dynamics, Early Childhood

\section{A. Pendahuluan}

Dalam Undang-Undang Republik Indonesia No. 20 th. 2003 tentang Sistem Pendidikan Nasional diamanatkanuntuk mengembangkan potensi peserta didik. Sistem pendidikan nasional adalah keseluruhan komponen pendidikan yang saling terkait secara terpadu untuk mencapai tujuan pendidikan nasional. ${ }^{1}$ Potensi yang dikembangkan tersebut mencakup aspek jasmani, rohani dan budi nurani peserta didik. Dengan demikian pendidikan anak usia dini merupakan hal yang sangat

$1 \quad$ Undang-undang No.20 Tahun 2003, tentang Sistem Pendidikan Nasional (Sisdiknas), Yogyakarta : Media Wacana Press, 2003,hlm.9. 
penting karena masa usia dini merupakan periode emas (golden age) bagi perkembangan anak untuk memperoleh proses pendidikan. Periode ini adalah tahun-tahun berharga bagi seorang anak untuk mengenali berbagai macam fakta di lingkungannya sebagai stimulus terhadap perkembangan kepribadian, psikomotorik, kognitif maupun sosialnya. Berdasarkan hasil penelitian, sekitar 50\% kapabilitas kecerdasannya orang dewasa telah terjadi ketika anak berumur 4 tahun, $80 \%$ telah terjadi ketika berumur 8 tahun, dan mencapai titik kulminasi ketika anak berumur sekitar 18 tahun ( Direktorat PAUD, 2004).

Hal ini berarti bahwa perkembangan yang terjadi dalam kurun waktu 4 tahun pertama sama besarnya dengan perkembangan yang terjadi pada kurun waktu 14 tahun berikutnya. Sehingga periode emas ini merupakan periode kritis bagi anak, dimana perkembangan yang diperoleh pada periode ini sangat berpengaruh terhadap perkembangan periode berikutnya hingga masa dewasa. Masa emas ini hanya datang sekali, untuk itu pendidikan untuk anak usia dini dalam bentuk pemberian rangsangan-rangsangan dari lingkungan terdekat sangat diperlukan untuk mengoptimalkan kemampuan anak.

Pola belajar yang diterapkan pada anak usia dini tidaklah sama dengan pola belajar pada anakusiaSD keatas. Untukitu perlu diperhatikan oleh penyelenggara program pendidikan pada anak usia dini bagaimana pengelolaan pendidikan yang baik sebagaimana telah diatur dalam UU tentang sistem pendidikan Nasional, terutama mengenai sumber belajar atau tenaga pendidik dalam melaksanakan kegiatan belajar mengajar..

\section{B. Pengertian Pendidikan Anak Usia Dini (PAUD)}

Pendidikan adalah usaha yang dijalankan dengan sengaja, teratur dan berencana dengan maksud mengubah tingkah laku manusia ke arah yang di inginkan. ${ }^{2}$ Dapat dikatakan jika selama proses pendidikan berlangsung tidak terjadi perubahan dalam perilaku anak, maka gagallah pendidikan itu.

Dalam undang-undang tentang sistem pendidikan nasional dinyatakan bahwa pendidikan anak usia dini adalah suatu upaya pembinaan yang ditujukan kepada anak sejak lahir sampai dengan usia enam tahun yang dilakukan melalui pemberian rangsangan pendidikan untuk membantu pertumbuhan dan perkembangan jasmani dan rohani agar anak memiliki kesiapan dalam memasuki pendidikan lebih lanjut

2 Dewi Salma Prawiradilaga dan Evelin Siregar, Mozaik Teknologi Pendidikan, 
(UU Nomor 20 Tahun 2003 Bab I Pasal 1 Ayat 14). ${ }^{3}$ Anak usia dini adalah kelompok anak yang berada dalam proses pertumbuhan yang bersifat unik, dalam arti memiliki pola pertumbuhan dan perkembangan (koordinasi motorik halus dan kasar), intelegensi (daya pikir, cipta, kecerdasan emosi dan kecerdasan spiritual), sosial emosional (sikap dan perilaku serta agama), bahasa dan komunikasi yang khusus sesuai dengan tingkat pertumbuhan dan perkembangan anak. ${ }^{4}$

Rentangan anak usia dini menurut Pasal 28 UU sisdiknas No. 20/2003 ayat 1 adalah 0-6 tahun. Sementara menurut kajian rumpun keilmuan PAUD dan penyelenggaraannya di beberapa Negara, PAUD dilaksanakan sejak usia 0-8 tahun.

Ruang lingkup Pendidikan Anak Usia Dini

1. Infant (0-1 tahun)

2. Toddler (2-3 tahun)

3. Preschool Kindergarten children (3-6 tahun)

4. Early Primary School (SD Kelas Awal) (6-8 tahun) ${ }^{5}$

Lebih lanjut, dalam UU Sisdiknas No.20 Tahun 2003 Ps.1 pendidikan anak usia dini dapat diselenggarakan dalam tiga jalur, yaitu :

1. Jalur formal antara lain diselenggarakan dalam bentuk taman kanakkanak, raudhlatul atfal, dan sejenisnya.

2. Jalur non formal antara lain taman penitipan anak, kelompok bermain, taman pendidikan Al-Qur'an, sekolah minggu dan sebagainya.

3. Jalur informal, pendidikan anak usia dini ditangani langsung oleh keluarga dan lingkungan. ${ }^{6}$

\section{Pentingnya Pendidikan Anak Usia Dini}

Berdasarkan pendapat para ahli pendidikan yang meyakini betapa pentingnya memberikan layanan pendidikan bagi anak usia dini. ${ }^{7}$

\section{Menurut Hurlock}

Bahwa semua anak yang baru lahir tidak berdaya sehingga membutuhkan bantuan orang dewasa untuk tumbuh dan

3 Undang-Undang Republik Indonesia Nomor 20 Tahun 2003 Tentang Sistem Pendidikan Nasional, dalam file pdf, hlm. 4.

4 Dr. Mansur, M.A, Pendidikan Anak Usia DIni Dalam Islam, Pustaka Pelajar, Yogyakarta,2005,hlm.88

5 ibid

6 Undang-undang No.20 Tahun 2003,op.cit.hlm.10

7 Dewi Salma Prawiradilaga dan Evelin Siregar, op.cit.,hlm 352 
berkembang, termasuk belajar. Pentingnya pendidikan bagi anak usia dini menurutnya adalah karena menciptakan interaksi edukatif yang diarahkan bagi perkembangan optimal seluruh potensi yang dimiliki anak. Dengan anak-anak yang memiliki kerangka dasar potensi yang kuat ketika usia dini, maka akan menjadi dasar dan penopang bagi perkembangan anak memasuki pendidikan lanjutan, berkarir maupun hidup di masyarakat kelak.

\section{Menurut Janek Doman dalam Dryden dan Vos}

Bahwa seorang anak yang baru lahir ke dunia adalah buta, tidak dapat mendengar dengan baik dan sensasinya jauh dari kesempurnaan, maka tugas orang tualah untuk membantu melihat, mendengar dan merasakan.

\section{Menurut Langeveld dalam Napitupulu}

Bahwa manusia adalah "animal education" atau hewan yang dapat dididik, jadi jika manusia tidak dididik, maka ia akan tetap sama dengan hewan lainnya. Artinya tiada perubahan tingkah laku dan akan melakukan segala tindakan berdasarkan naluri (instinct).

Berdasarkan ketiga pendapat tersebut, jelaslah bahwa pentingnya pendidikan bagi anak usia dini adalah agar anak dapat mengembangkan seluruh potensi yang dimilikinya melalui berbagai pemberian rangsangan dari orang dewasa dan atau lingkungan sekitar, agar anak dapat menjadi manusia yang memiliki derajat kemanusiaan sesuai dengan harkat dan martabat sebagai khalifah di muka bumi.

Selain itu, pentingnya pemberian layanan pendidikan anak usia dini, memiliki beberapa fungsi : ${ }^{8}$

1. Fungsi Adaptasi dan Sosialisasi

Yakni berperan dalam membantu anak melakukan penyesuaian diri dengan berbagai lingkungan serta menyesuaikan diri dengan keadaan dalam dirinya sendiri dan juga membantu anak agar ia memiliki keterampilan-keterampilan sosial yang berguna dalam pergaulan masyarakat.

2. Fungsi Pengembangan

Yang berkaitan dengan peranan pendidikan anak usia dini dalam mengambangkan berbagai potensi yang dimiliki anak. Setiap unsurnya membutuhkan suatu situasi dan lingkungan yang dapat menumbuhkembangkan potensi tersebut ke arah perkembangan 
yang optimal sehingga menjadi potensi yang bermanfaat bagi anak itu sendiri dan lingkungannya.

3. Fungsi Bermain

Yakni peranan pendidikan anak usia dini dalam memberikan kesempatan pada anak untuk bermain, melalui bermain anak akan senang dan gembira mengembangkan berbagai potensi yang dimilikinya.

4. Fungsi Ekonomik

Yakni pendidikan yang terencana pada anak usia dini merupakan investasi jangka panjang yang dapat menguntungkan pada setiap rentang perkembangan selanjutnya. Terlebih lagi investasi yang dilakukan berada pada masa keemasan (the golden age) yang akan memberikan keuntungan berlipat ganda. Melalui fondasi ini anak-anak akan menghadapi masa depanya dengan perbekalan yang cukup kuat dan banyak sehingga ia dapat mengatasi berbagai permasalahan yang akan dihadapinya.

\section{Landasan Pendidikan Anak Usia Dini}

Dasar yuridis PAUD merupakan landasan penyelenggaraan PAUD yang terdiri dari ketentuan peraturan perundang- undangan yang secara hierarkis diberlakukan di Indonesia yang bersifat mengikat jajaran penyelenggara negara dan warga negara. Kondisi dasar yuridis menjadi penentu eksistensi PAUD dalam konteks kehidupan bernegara, dalam pengertian kekokohan dasar yuridis menentukan kekokohan PAUD, dan begitu jua sebaliknya. Oleh Zuhairini dan kawan-kawan, dasar yuridis ini dibedakan menjadi tiga macam. Pertama, dasar ideal yang terdiri dari Pancasila sebagaimana termaktub dalam pembukaan Undang-Undang Dasar 1945 sebagai falsafah (way of life) bangsa Indonesia yang memperlihatkan visi kehidupan yang harus diwujudkan. Kedua, dasar struktural yang terdiri dari Undang-Undang Dasar 1945 yang memperlihatkan misi yang harus diemban dalam merealisasikan berbagai hubungan hak dan kewajiban baik secara nasional antar institusi kenegaraan dan antara negara dengan warga negara maupun secara internasional. Ketiga, dasar operasional yang terdiri dari ketentuan-ketentuan yang yang lebih spesifik secara langsung mengatur pelaksanaan mengenai suatu aspek kehidupan semisal mengenai PAUD. 9

9 Zuhairini, et.al, Metodik Khusus Pendidikan Agama, Biro Ilmiah Fakultas Tarbiyah 
Kondisi dasar yuridis pendidikan anak usia dini adalah tampak semakin kokoh lagi semakin lengkap; sebagai landasan ideal adalah Pancasila sebagai termaktub dalam pembukaan undang-undang dasar negara 1945; sebagai landasan struktural adalah undang-undang dasar negara 1945; dan sebagai landasan operasional adalah Undang-Undang Republik Indonesia Nomor 23 Tahun 2002 Tentang Perlindungan Anak, Undang-Undang Republik Indonesia nomor 20 tahun 2003 tentang Sistem Pendidikan Nasional, Peraturan Pemerintah Republik Indonesia Nomor 19 Tahun 2005 Tentang Standar Nasional Pendidikan, Peraturan Pemerintah Republik Indonesia Nomor 17 Tahun 2010 Tentang Pengelolaan dan Penyelenggaraan Pendidikan (sebagai diubah dengan Nomor 66 Tahun 2010), Peraturan Menteri Pendidikan Nasional Republik Indonesia Nomor 58 Tahun 2009 Tentang Standar Pendidikan Anak Usia Dini, Peraturan Menteri Pendidikan Nasional Nomor 36 Tahun 2010 Tentang Organisasi dan Tata Kerja Kementerian Pendidikan Nasional yang dalam bab I pasal 4c menyebut Direktorat Jenderal Pendidikan Anak Usia Dini, Nonformal, Informal beserta tugas-tugasnya, dan dalam bab IV pasal 110b menyebut Direktorat Pembinaan Pendidikan Anak Usia Dini beserta tugas-tugasnya, Petunjuk Teknis Penyelenggaraan POS PAUD yang diterbitkan oleh Direktorat Pembinaan Pendidikan Anak Usia Dini pada 2011, dan Petunjuk Teknis Penyelenggaraan PAUD Berbasis Taman Pendidikan Al- Qur'an (PAUD-TPQ) yang diterbitkan oleh Direktorat Pembinaan Pendidikan Anak Usia Dini pada 2011

\section{E. Prinsip Pendidikan Anak Usia Dini}

Prinsip pelaksanaan program PAUD harus mengacu pada prinsip umur yang terkandung dalam konvensi hak anak,yaitu : ${ }^{10}$

1. Non diskriminasi, dimana semua anak dapat mengecap pendidikan anak usia dini tanpa membedakan suku bangsa, jenis kelamin, bahasa, agama, tingkat sosial serta kebutuhan khusus setiap anak.

2. Dilakukan demi kebaikan terbaik untuk anak (the best interest of the child), bentuk pengajaran, kurikulum yang diberikan harus sesuai dengan tingkat perkembangan kognitif, emosional,konteks sosial budaya dimana anak-anak hidup.

3. Mengakui adanya hak hidup, kelangsungan hidup dan perkembangan yang sudah melekat pada anak. 
4. Penghargaan terhadap anak (respect for the views of the child) pendapat anak yang menyangkut kehidupannya perlu mendapatkan perhatian dan tanggapan.

Dengan demikian pendidikan yang diberikan pada anak usia dini yaitu untuk menyiapkan potensi kecerdasan yang dimiliki anak. Upaya untuk mencerdaskan anak-anak diperlukan semangat, kepedulian, kerja keras, pengorbanan dan pemahaman yang baik tentang pendidikan.

\section{F. Problem Yang Dihadapi dalam Pengelolaan Pendidikan Anak Usia Dini}

Pemerintah telah melakukan berbagai usaha untuk meningkatkan pendidikan anak usia dini di Indonesia, namun pendidikan anak usia dini masih banyak menghadapi persoalan yang kompleks dan saling terkait satu sama lainnya. Ekonomi yang lemah akan mempengaruhi kualitas gizi makanan anak. Kondisi demikian menyebabkan potensi genetisnya tidak dapat berkembang secara optimal sehingga pertumbuhan badan dan intelektual anak bisa terhambat.

Kondisi ekonomi yang lemah ditambah dengan tingkat pendidikan ibu dan calon ibu yang rendah dapat menyebabkan rendahnya kualitas asuhan terhadap anak usia dini. Hal ini akan mempengaruhi pengetahuan ibu atau calon ibu mengenai kebutuhan gizi yang baik dan diperlukan anak serta pola asuh dan cara mendidik sesuai masa perkembangan anak. Ketidakmengertian ibu atau calon ibu terhadap masa emas anak bisa dikarenakan ketidakmampuan membeli buku-buku tentang merawat dan mendidik anak, dan sebagian lagi tidak sempat membaca buku-buku tersebut karena kesibukannya bekerja untuk memenuhi kebutuhan hidupnya.

Ekonomi keluarga yang lemah juga dapat mempengaruhi kualitas pendidikan anak usia dini. Dengan kondisi ekonomi yang lemah banyak orang tua yang tidak sanggup membayar tinggi untuk pendidikan anaknya. Hal ini menyebabkan kualitas pelayanan PAUD tidak seperti yang diharapkan. Layanan PAUD yang berkualitas umumnya hanya terdapat di kota-kota besar. Selain itu, kuantitas PAUD antara lain disebabkan adanya persepsi yang salah mengenai pendidikan anak usia dini dan TK . Pendidikan anak usia dini dan TK dianggap pendidikan pra sekolah yang tidak wajib bagi anak menyebabkan pendidikan anak usia dini tidak perlu dikembangkan sebaik pendidikan dasar dan menengah. 241 
Persepsi seperti ini harus dibenahi, mengingat anak usia 0-8 tahun, bahkan 0-5 tahun merupakan masa golden age atau masa emas yang sangat berharga untuk menumbuhkembangkan potensi anak.

Selain kuantitas PAUD, kualitas guru PAUD juga masih rendah. Banyak guru TK berasal dari SPG-TK, SPG, bahkan lulusan SLTA dan SLTP. Kondisi ini diperparah dengan adanya otonomi daerah karena banyak daerah yang tidak mampu mengangkat dan menggaji guru TK. Banyak guru TK yang digaji jauh di bawah kebutuhan hidup minimal, bahkan lebih rendah dari pembantu rumah tangga. Kondisi tersebut menyebabkan mutu guru rendah. ${ }^{11}$

\section{G. Pihak-pihak yang Berperan dalam PAUD}

Pihak-pihak yang terlibat dalam pengelolaan Pendidikan Anak Usia Dini adalah pemerintah, masyarakat dan keluarga. Keluarga adalah institusi pertama yang melakukan pendidikan dan pembinaan terhadap anak karena di sanalah pertama kali dasar-dasar kepribadian anak dibangun. Anak dibimbing bagaimana ia mengenal Penciptanya agar kelak ia hanya mengabdi kepada Sang Pencipta Allah swt. Demikian pula dengan pengajaran perilaku dan budi pekerti anak yang didapatkan dari sikap keseharian orang tua ketika bergaul dengan mereka. Bagaimana anak diajarkan untuk berbuat baik, bersikap sopan santun, saling mengasihi terhadap saudara dan orang lain. Anak juga diajarkan untuk memilih cara yang benar ketika memenuhi kebutuhan hidup dan memilih barang halal yang akan mereka gunakan. Intinya potensi dasar untuk membentuk generasi berkualitas dipersiapkan oleh keluarga.

Masyarakat juga tidak kalah pentingnya perannya terhadap anak. Karena masyarakat yang menjadi lingkungan anak menjalani aktivitas sosialnya mempunyai peran yang besar dalam mempengaruhi baik buruknya proses pendidikan, karena anak satu bagian yang tidak terpisahkan dari masyarakat. Interaksi dalam lingkungan ini sangat diperlukan dan berpengaruh dalam pertumbuhan dan perkembangan anak, baik secara fisik maupun biologis. Masyarakat yang menjadi lingkungan hidup generasi tidak saja para tetangga tetapi juga termasuk sekolah dan masyarakat dalam satu Negara. Karena itu para tetangga, para pendidik dan juga pemerintah sebagai penyelenggara urusan Negara bertanggung jawab dalam proses pendidikan generasi.

11 Selamet Suyoto, Dasar-dasar Pendidikan Anak Usia Dini (Yogyakarta: Hikayat Publishing,2005) Cet. 1,hlm.231-234 
Negara sebagai penyelenggara pendidikan generasi yang utama, wajib mencukupi segala sarana untuk memenuhi kebutuhan pendidikan umat secara layak. Atas dasar ini Negara wajib menyempurnakan pendidikan bebas biaya akan membuka peluang yang sebesar-besarnya bagi setiap individu rakyat untuk mengenyam pendidikan, sehingga pendidikan tidak hanya menyentuh kalangan tertentu saja , dan tidak dijadikan bisnis yang bisa mengurangi mutu pendidikan itu sendiri. Padahal mutu pendidikan sangat mempengaruhi corak generasi yang dihasilkannya.

Negara wajib menyediakan tenaga-tenaga pendidik yang handal. Mereka yang memiliki kepribadian Islam yang luhur, punya semangat pengabdian yang tinggi dan mengerti filosofis pendidikan generasi serta cara-cara yang harus dilakukannya, karena mereka adalah tauladan bagi anak didiknya. Kelemahan sifat pada pendidik berpengaruh besar terhadap pola pendidikan generasi. Seorang guru tidak hanya menjadi penyampai ilmu pada muridnya tetapi juga sebagai seorang pendidik dan Pembina generasi.

Agar para pendidik bersemangat dalam menjalankan tugasnya tentu saja Negara harus menjamin kehidupan materi mereka. Ini dapat memberi motivasi lebih pada mereka meski tugas mereka tidak ditunjukkan semata untuk memperoleh materi, tetapi merupakan ibadah yang mempunyai nilai tersendiri di sisi Allah swt. Jasa para pendidik dan pengabdian mereka harus mendapat penghargaan, dan ini merupakan tanggung jawab Negara. Tugas dan tanggung jawab guru sebagai petugas profesi bidang pendidikan untuk dapat memberdayakan anak didik sebagai individu unik dan memiliki karakteristik tersendiri sampai mampu menjadikan anak didiknya mencapai dewasa sesuai dengan tujuan pendidikan pada satuan pendidikan TK. ${ }^{12}$

Ada dua tujuan diselenggarakannya pendidikan anak usia dini yaitu:

1. Tujuan utama : untuk membentuk anak Indonesia yang berkualitas, yaitu anak yang tumbuh dan berkembang sesuai dengan tingkat perkembangannya sehingga memiliki kesiapan yang optimal di dalam memasuki pendidikan dasar serta mengarungi kehidupan di masa dewasa.

2. Tujuan penyerta : untuk membantu menyiapkan anak mencapai kesiapan belajar di sekolah. 


\section{H. Reformasi Kontemporer Pengelolaan Pendidikan Anak Usia Dini}

Lembaga pendidikan anak usia dini kini harus menyelaraskan langkah dan memfokuskan perhatian pada anak-anak, bukan sekedar tuntutan masyarakat atau orang tua. Kurikulum dan proses pembelajaran harus diatur sedemikian rupa sehingga sesuai dengan dunia anakanak. Para pendidiknya harus memiliki mindset tentang anak-anak dan dunianya, yang bukan miniatur orang dewasa. Keistimewaan dan keunikan anak harus mulai dihargai.

Semua lembaga pendidikan anak usia dini mulai berjalan seirama dalam upaya perluasan akses dan peningkatan kualitas pendidikan. Sinergisme perlu dibangun bersama-sama, sehingga seluruh anak usia dini dapat tertangani. Dengan sinergisme ini permasalahan pendidikan anak usia dini akan terasa ringan, karena kita semua memahami bahwa permasalahannya di bidang ini amatlah kompleks, mulai dari banyaknya anak-anak dari kelompok masyarakat marginal yang belum terlayani, sulitnya akses karena permasalahan geografis, keterbatasan tenaga dari segi kualitas dan kuantitas, kurangnya fasilitas, sarana, prasarana dan sebagainya.

Sinergisme hanya dapat dibangun ketika semua pihak menyadari bahwa tidak mungkin permasalahannya pendidikan anak usia dini dapat ditangani sendiri-sendiri.

Bentuk-bentuk sinergis yang dapat dilakukan antara lain:

1. Sharing dalam sumber daya manusia

2. Sharing dalam konsep dan pemikiran, misalnya pengembangan model pembelajaran PAUD, dan sejenisnya.

3. Sharing pendanaan kegiatan, sharing waktu dan tempat penyelenggaraan kegiatan dan sebagainya. ${ }^{13}$

Tiga substansi dasar yang menjadi patologi atau penyakit pendidikan yang sampai saat ini belum juga teratasi. Pertama, buruknya mutu pendidikan juga dapat dilihat dari pengembangan sumber daya manusia yang dinyatakan dalam Human Development Index (HDI).

Kedua, cerminan sikap atau watak manusia Indonesia yang masih belum menampakkan sikap yang menjunjung nilai-nilai kejujuran, kebenaran, dan rasa tanggung jawab (sikap kedewasaan).

Ketiga, yang paling memprihatinkan lagi adalah minimnya

13 ]http://www.bpplsp-reg4.go.id/index.php?option=com_content\&task=view\& id $=40$ \&itemid $=1$ 
keterampilan yang dimiliki, sehingga kemandirian dalam hal ekonomi setelah menyelesaikan sebuah jenjang pendidikan kurang terwujud.

Ketiga hal itu merupakan sasaran utama yang harus diwujudkan dalam pembangunan pendidikan dalam perspektif makro. Pembangunan pendidikan merupakan prioritas yang harus dipikirkan dan direncanakan bagaimana formulasi yang tepat.

Pemberdayaan sumber daya manusia merupakan kunci utama dalam meningkatkan dan mengembangkan kualitas pendidikan. Peserta didik akan memiliki pribadi yang baik bila diasuh oleh pendidik yang memiliki kepribadian yang baik pula, murid akan memiliki keinginan belajar yang tinggi bila dididik oleh pendidik yang mempunyai animo tinggi untuk belajar, anak akan memiliki keterampilan bila dibimbing oleh pembimbing yang cekatan dan tanggap lingkungan, anak dapat hidup berdisiplin, bersih, tertib bila dibina oleh pendidik yang memiliki pola hidup teratur, demikian seterusnya.

Dibutuhkan formula yang tepat dalam mengatur segala permasalahan manajemen Pendidikan Anak Usia Dini (PAUD). Salah satu pendekatan baru dalam perencanaan publik yang sedang digalakan adalah perencanaan partisipatif, yakni dengan melibatkan semua pihak yang terlibat dalam kegiatan mulai dari perencanaan, pelaksanaan, evaluasi, sampai pemanfaatan program yang direncanakan. Hal ini didasari oleh asumsi bahwa orang yang merasa terlibat dalam proses sejak perencanaan sampai tahap akhir merasa ikut memiliki dan ikut bertanggung jawab terhadap keberhasilan program. Dalam hal ini dirasa perlu melibatkan para tokoh agama masyarakat, dan orang-orang yang memiliki kemampuan ekonomi cukup.

Apabila tahap perencanaan telah dilaksanakan, maka langkah selanjutnya adalah pengorganisasian, yakni menyusun dan merangkai unsur sumber daya organisasi dan lingkungan yang ada sehingga bisa dicapai hasil yang maksimal. Kelemahan yang banyak dilakukan oleh masyarakat kita dalam mengorganisasikan sumber daya manusia PAUD adalah menentukan orangnya terlebih dahulu, baru kemudian organisasinya. Padahal, tahap pengorganisasian yang benar adalah menentukan pekerjaan apa saja yang diperlukan untuk mencapai tujuan organisasi, lalu unit-unit yang melakukan pekerjaan tersebut, kemudian disusun struktur organisasi yang menempatkan masing-masing unit tersebut dalam rangkaian struktur organisasi yang sinergis, lalu ditentukan kualifikasi tenaga-tenaga yang diperlukan untuk menangani 
masing-masing unit.

Dalam menempatkan personal hendaknya diingat prinsip menempatkan orang pada tempat yang tepat sesuai dengan kompetensi dan kualifikasi pada waktunya. Hendaknya dihindari menempatkan personal berdasarkan faktor suka atau tidak suka. Kelemahan lain dalam pengorganisasian PAUD adalah mekanisme hubungan interaksi antar segenap pihak dalam lembaga. Pengorganisasian pada dasarnya menempatkan masing-masing personal dalam tata hubungan yang sistemik, sehingga jelas siapa mengerjakan apa dan bertanggung jawab kepada siapa.

Selanjutnya adalah ukuran keberhasilan kerja yang tidak jelas. Hal ini erat kaitanya dengan budaya kita yang "just do it" atau pokoknya sudah melakukan. Akibatnya proses pengukuran (kriteria) keberhasilan kinerja personal tidak dilakukan atau kalau dilakukan maka pengukurannya tidak objektif.

Terakhir, tiadanya norma tertulis. Kelemahan umum dari lembaga PAUD adalah organisasi berjalan secara informal dan tidak tertulis meskipun itu menyangkut organisasi formal yang perlu landasan tertulis. Dalam aturan tertulis, perlu diatur mekanisme hubungan organisasional antar personal, arus pekerjaan dan tanggung jawab serta sanksi-sanksi dan aturan-aturan lain diperlukan.

Ada beberapa hal yang perlu diperhatikan dalam menjalankan PAUD :

1. Iklim kebersamaan yang sehat. Organisasi adalah kerjasama antar dua orang atau lebih sehingga keberhasilan organisasi adalah berkat kerjasama beberapa orang, dan bukan atas hasil kerja seseorang atau sekelompok orang yang mengaku-ngaku paling berjasa.

2. Keadilan bagi pendidik. Seorang pendidik yang merasa diperlakukan tidak adil akan turun kinerjanya. Rasa tidak adil bisa muncul dalam berbagai peluang, antara lain dalam pengangkatan jabatan yang tidak terbuka, atau perbedaan dalam pemberian ganjaran dan sanksi.

3. Penghargaan terhadap kinerja pendidik. Penghargaan di sini tidak hanya berupa materi melainkan juga penghargaan yang berupa immaterial, seperti pujian atau peningkatan status.

Dalam menata PAUD di samping adanya Planning (perencanaan), Organizing (pengorganisasian), Actuating (Pelaksanaan), juga 
disingkat dengan POAC. Tanpa adanya pengendalian, maka jalanya organisasi tidak akan berjalan efektif dan efisien dalam mencapai tujuan. 14

Yang menjadi tujuan dasar dari pengendalian :

1. Apakah jalanya organisasi telah ada pada jalur yang benar ?

2. Apakah target bisa dicapai secara kuantitas, kualitas, dan dalam jangka waktu tertentu?

Pertanyaan pertama mengacu pada apakah cara melakukan pekerjaan sesuai dengan yang telah dilakukan dalam jabaran kerja (job description). Sedang yang kedua mengacu pada apakah hasil pekerjaan (out-put) yang ditetapkan bisa dicapai sesuai dengan target waktu, jumlah dan kualitas.

Untuk itulah perlu ditetapkan siapa yang akan melakukannya. Yayasan penyelenggara PAUD memiliki hak dan fungsi sebagai pengendali kegiatan belajar mengajar PAUD. Namun permasalahannya adalah, kebanyakan personal yang menjadi pengurus bidang pendidikan kurang atau tidak menguasai apa yang seharusnya dilakukan oleh lembaga penyelenggara. Hal ini didasari oleh kurangnya kualitas SDM, juga seringnya menempatkan personal yang tidak tepat pada suatu jabatan dalam organisasi.

Dalam kaitannya dengan kompleksitas kelembagaan PAUD, maka yang harus ditentukan terlebih dahulu adalah bentuk kelembagaan PAUD (TK, KB, TPA,TPG). Selanjutnya adalah merangkai lebih lanjut sumber daya organisasi, baik manusianya maupun non manusianya dalam jaringan tata kerja organisasi PAUD struktural, kualifikasi tenaga yang menanganinya, baru kemudian merekrut tenaga yang memenuhi kualifikasi yang ditentukan dengan memperhatikan prinsip-prinsip pengorganisasian. Langkah lain yang tidak bisa ditinggalkan adalah merangkai kerjasama dengan berbagai pihak dalam tatanan jaringan kerja yang saling menguntungkan.

Dengan demikian, yang perlu diperhatikan dalam menjalankan PAUD. Pertama, adalah adanya iklim kebersamaan yang sehat. Kerjasama antar dua orang atau lebih sehingga keberhasilan lembaga adalah berkat kerjasama beberapa orang, dan bukan atas hasil kerja seseorang atau sekelompok orang yang mengaku-ngaku paling berjasa. Kedua adalah,

14 Nanang Fatah, Landasan Manajemen Pendidikan, Bandung: Remaja Rosda Karya, 2006.hlm.22 
keadilan bagi pendidik dan tenaga kependidikan. Seseorang yang merasa diperlakukan tidak adil akan menurun kinerjanya. Dan ketiga adalah, penghargaan terhadap kinerja pendidik. Penghargaan di sini tidak hanya berupa materi melainkan juga penghargaan yang berupa immaterial, seperti pujian atau peningkatan status.

\section{Kesimpulan}

Pendidikan anak usia dini untuk menyiapkan potensi kecerdasan anak, pendidikan anak usia dini yaitu suatu proses pembinaan tumbuh kembang anak usia lahir hingga 6 tahun secara menyeluruh yang mencakup aspek fisik dan non fisik, dengan memberikan rangsangan bagi perkembangan jasmani, rohani (moral dan spiritual), motorik, akal pikir, emosional dan sosial yang tepat agar anak dapat tumbuh dan berkembang secara optimal.

Sedangkan pentingnya pendidikan anak usia dini adalah agar anak dapat mengembangkan seluruh potensi yang dimilikinya melalui berbagai pemberian rangsangan dari orang dewasa dan lingkungan sekitar.

Pendidikan anak usia dini merupakan pendidikan yang sangat mendasar dan strategis dalam pembangunan sumber daya manusia. Tidak mengherankan apabila banyak Negara menaruh perhatian yang sangat besar terhadap penyelenggaraan pendidikan anak usia dini. Di Indonesia sesuai pasal 28 Undang-undang Nomor 20 Tahun 2003 tentang Sistem Pendidikan Nasional, pendidikan anak usia dini telah ditempatkan sejajar dengan pendidikan lainya. Bahkan pada puncak peringatan Hari Anak Nasional tanggal 23 Juli 2003, Presiden Republik Indonesia telah mencanangkan pelaksanaan pendidikan anak usia dini di seluruh Indonesia demi kepentingan terbaik anak Indonesia (Direktorat PAUD, 2004).

Program ini bertujuan agar semua anak usia dini (usia 0-6 tahun), baik laki-laki maupun perempuan memiliki kesempatan tumbuh dan berkembang optimal sesuai dengan potensi yang dimilikinya, sesuai tahap-tahap perkembangan atau tingkat usia mereka. PAUD juga merupakan pendidikan persiapan untuk mengikuti jenjang pendidikan sekolah dasar. Secara spesifik, program ini bertujuan untuk meningkatkan akses dan mutu pelayanan pendidikan melalui jalur formal seperti Taman Kanak-kanak (TK), Raudhatul Athfal (RA), dan bentuk lain yang sederajat, serta jalur pendidikan non-formal berbentuk 
Kelompok Bermain (KB), Taman Penitipan Anak (TPA) atau bentuk lain yang sederajat, dan jalur informal berbentuk pendidikan keluarga atau pendidikan yang diselenggarakan oleh lingkungan. 


\section{DAFTAR PUSTAKA}

Dewi Salma Prawiradilaga dan Evelin Siregar, Mozaik Teknologi Pendidikan, Prenada Media, Jakarta, 2004

Dr. Mansur, M.A, Pendidikan Anak Usia Dini Dalam Islam, Pustaka Pelajar, Yogyakarta,2005

Nanang Fatah, Landasan Manajemen Pendidikan, Bandung: Remaja Rosda Karya, 2006.

Selamet Suyoto, Dasar-dasar Pendidikan Anak Usia Dini (Yogyakarta: Hikayat Publishing,2005) Cet. 1

Undang-undang No.20 Tahun 2003, tentang Sistem Pendidikan Nasional (Sisdiknas), Yogyakarta : Media Wacana Press, 2003

Zuhairini, et.al, Metodik Khusus Pendidikan Agama, Biro Ilmiah Fakultas Tarbiyah IAIN Sunan Ampel Malang, 1981

Vide, "Perkembangan Anak pada Masa Usia Dini", online, http://www. ibudanbalita.net/938/perkembangan-anak-pada-masa-usia-dini. html

http://www.jeo-8.blogspot.com/\#artikel4

http: / / www.bp plsp-reg4.go.id/index.php? option=com content\&task=view\&id=40\&itemid=1 